DOI: $10.2478 /$ lpts-2019-0012

\title{
INVESTIGATION OF EDFA PERFORMANCE IN DWDM TRANSMISSION SYSTEMS UNDER DIFFERENT OPERATING CONDITIONS
}

\author{
J. Putrina, S. Olonkins, V. Bobrovs, J. Porins \\ Institute of Telecommunications, Riga Technical University \\ 12 Azenes Str., Riga, LV-1048, LATVIA \\ Sergejs.olonkins@rtu.lv
}

\begin{abstract}
The article investigates dependence of EDFA performance on its operating conditions. First of all, the impact of changes in channel spacing on the quality of the amplifier signal and on the desired EDFA configuration is observed - three different values of channel spacing are considered -37.5 $\mathrm{GHz}, 50 \mathrm{GHz}$ and $100 \mathrm{GHz}$. Afterwards, the impact of EDFA positioning on the quality of the amplified signal and the desired configuration is assessed. Three different EDFA positioning scenarios are considered - when the EDFA is used as a power booster, as an in-line amplifier and as a preamplifier. In all cases, such configuration of the EDFA is found that can ensure bit-error ratio (BER) values below $1 \cdot 10^{-9}$ in all channels of the system. To assess the performance of the amplifiers, power penalty values are obtained in respect to identical transmission systems but without amplification.
\end{abstract}

Keywords: Amplifier positioning, channel spacing, erbium-doped fiber amplifiers, wavelength division multiplexing.

\section{INTRODUCTION}

The throughput of fibre optical transmission systems has experienced a significant increase during the past decades. This tendency is mostly driven by the alltime growing popularity and availability of online multimedia services and machineto-machine applications. According to the Cisco virtual networking index forecast, it is expected that monthly global IP traffic will reach 396 Exabytes till the end of 2022 [1]. Huge effort is made to increase the throughput of future optical networks and to improve performance of the existing transmission systems. The two most common ways of increasing capacity of existing wavelength division multiplexed (WDM) transmission systems is to increase the bit rate per channel or to ensure simultaneous transmission of a higher number of channels [2], [3].

Implementation of any of the two above-mentioned approaches results in stricter requirements for the quality of the transmitted signal in WDM systems. At this point, optimisation of performance of optical amplifier becomes curtail, as this network element is the main source of optical signal impairments. Erbium-doped fibre amplifiers (EDFAs) are the most frequently used type of amplifiers in modern 
optical networks, as they operate in the wavelength region where minimal optical signal attenuation is observed (1530-1565 nm) in standard single mode fibres, and as they are relatively easy to build. EDFAs are also known for their high energy transfer efficiency ( $>50 \%$ of pump energy is used for excitation of $\mathrm{Er}^{+3}$ ions), almost complete polarization insensitivity and relatively low noise characteristics [4], [5].

Performance of EDFAs is highly dependent on such amplifier parameters as erbium-doped fibre (EDF) length, pump power, pump wavelengths and pump propagation direction. These parameters have direct impact on the achieved level of population inversion in the gain medium, and, therefore, incorrect choice of at least one of these parameters will lead to changes in the shape of the gain spectrum, the achieved level of amplification and on the amount of produced amplified spontaneous emission (ASE) noise [6], [7]. Furthermore, the performance of the amplifier is also highly dependent on the conditions in which the amplifier is operating. Any adjustments in system configuration that will lead to changes in input signal power or the width of the wavelength band to be amplified will impact the total system performance as well as the configuration of the EDFA that would be optimal for the system under attention [5], [8].

The goal of this article is to investigate how changes of channel spacing and of input signal power influence the performance of Erbium-doped fibre amplifiers. While choosing EDFA configuration for every system setup, the aim is to find the lowest pump power that will ensure the required quality of the signal in order to avoid excessive pumping, which may result in additional amplified signal discrepancies.

\section{INVESTIGATION OF CHANNEL SPACING IMPACT ON EDFA PERFORMANCE IN WDM TRANSMISSION SYSTEMS}

The gain spectrum of EDFAs is strictly wavelength dependent due to the molecular structure of the Erbium doped fibre; its width is limited approximately to $40 \mathrm{~nm}$ for conventional EDFAs. As there is a need to increase the capacity of WDM transmission systems, the obvious solution of enhancing the total transmission speed of existing systems with EDFAs is to decrease channel spacing in order to ensure simultaneous transmission of a larger number of channels over the limited gain bandwidth. Changes in channel spacing may have direct impact on the performance of the whole system and, therefore, after such changes re-adjustment of amplifier parameters is required in order to find the most suitable EDFA configuration for the system under attention. The goal of this section is to assess the impact of changing channel spacing in a WDM transmission system on the performance of EDFAs.

OptSim 5.2 simulation software was used to obtain the results introduced in this article. As experience shows, it is capable of handling complex simulations of multichannel optical transmission systems and of ensuring high accuracy results without high performance requirements for the hardware it is operating on [9]-[11]. In order to assess the impact of channel spacing on the performance of EDFAs, a simulation model of a $9.953 \mathrm{Gbps}$ WDM transmission system with non-return to zero intensity on-off keying modulation (NRZ-OOK) transmission distance of 150 $\mathrm{km}$ and an in-line EDFA introduced. This simulation model is shown in Fig.1. 
Each transmitter consists of a data source, NRZ coder and a continuous wave laser, the $6 \mathrm{dBm}$ output radiation of which is modulated by an external Mach-Zehnder modulator. Each transmitter operated at its own frequency, dependent on the channel spacing used in the system. Three different channel spacing values are observed: $37.5 \mathrm{GHz}, 50 \mathrm{GHz}$ and $100 \mathrm{GHz}$. The centre frequencies of the 16 transmitters are distributed throughout the following frequency ranges: from 193.1 to $193.6625 \mathrm{THz}$ (37.5 GHz channel spacing), from $193 \mathrm{THz}$ to $193.75 \mathrm{THz}$ (50 GHz channel spacing) and from 192.6 to $194.1 \mathrm{THz}$ (100 GHz channel spacing).

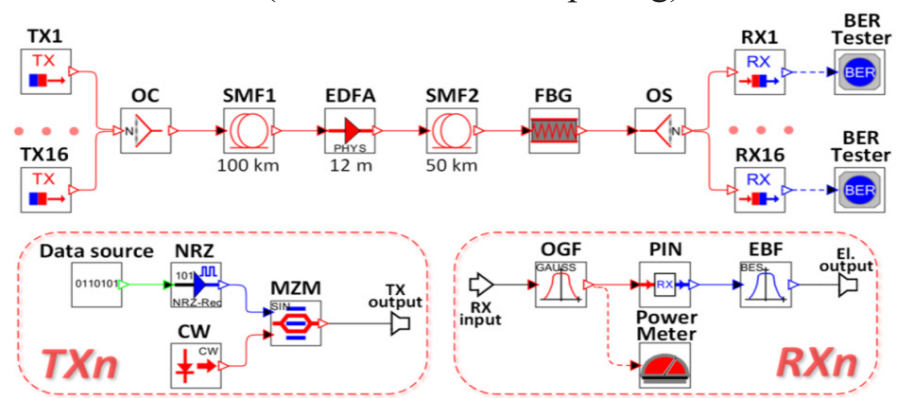

Fig. 1. Simulation model of 16 channel 9.953 Gbit/s WDM transmission system with NRZ-OOK modulation format and an in-line EDFA.

The output optical radiation of all 16 transmitters is combined into a single optical flow and sent through a $150 \mathrm{~km}$ long optical link, which consists of two sections $(100 \mathrm{~km}$ and $50 \mathrm{~km}$ ) of standard single-mode fibre (SMF) with $0.2 \mathrm{~dB}$ attenuation and $17 \mathrm{ps} / \mathrm{nm} / \mathrm{km}$ chromatic dispersion at $1550 \mathrm{~nm}$ reference wavelength. The in-line EDFA is placed in between the two sections of the transmission line. After processing through the second SMF, the signal is sent through a fibre Bragg grating (FBG) for dispersion compensation purposes (total amount of compensated dispersion is $2550 \mathrm{ps} / \mathrm{nm}$ ) and divided among 16 PIN photodiode based receivers with sensitivity of $-20.5 \mathrm{dBm}$ for $1 \cdot 10^{-9}$ reference bit-error ratio (BER).

Before choosing the configuration of the EDFA it is necessary to adjust the $-3 \mathrm{~dB}$ bandwidth of bandpass optical filters at the receiver end. For this purpose, the dependence of the maximal BER among all 16 channels (systems maximal BER) on the $-3 \mathrm{~dB}$ bandwidth of optical filters is obtained at each channel spacing in a system without amplification and with transmission distance of $40 \mathrm{~km}$. The obtained results are shown in Fig.2.

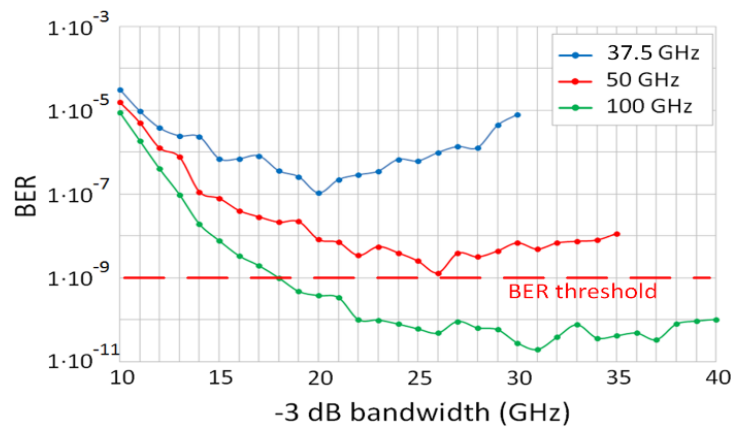

Fig. 2. Systems maximal BER value dependence on the $-3 \mathrm{~dB}$ bandwidth of the optical filters for 35.7 (blue), 50 (red) and $100 \mathrm{GHz}$ (green) channel spacing in the system without amplification. 
As can be seen in Fig.2, in case when $100 \mathrm{GHz}$ channel spacing, systems maximal BER value reaches its minimum $\left(1.96 \cdot 10^{-11}, 13^{\text {th }}\right.$ channel) when the $-3 \mathrm{~dB}$ bandwidth of optical filters is set to $31 \mathrm{GHz}$, in case of $50 \mathrm{GHz}$ channel spacing - to $26 \mathrm{GHz}\left(2.98 \cdot 10^{-9}, 8^{\text {th }}\right.$ channel), and in case of $37.5 \mathrm{GHz}$ channel spacing - to 20 $\mathrm{GHz}\left(1.07 \cdot 10^{-7}, 4^{\text {th }}\right.$ channel). These results demonstrate that if the $-3 \mathrm{~dB}$ bandwidth of optical filters is too small, part of the corresponding channel signal energy is filtered out, which causes severe signal quality degradation, and, on the contrary, if it is too big - part of the energy that belongs to the neighbouring channels is not filtered out and causes an increase of BER for the corresponding channel.

The in-line EDFA was based on a 12-meter long EDF, in which the $980 \mathrm{~nm}$ pumping radiation was propagating in the same direction as the amplified signal. The $980 \mathrm{~nm}$ wavelength was selected because, in general, at relatively high pump powers (30-100 $\mathrm{mW}$ ) and relatively short spans of EDF, the $980 \mathrm{~nm}$ pump is capable of ensuring higher amplification efficiency than the $1480 \mathrm{~nm}$ pump, as due to the nonzero emission cross-section at $1480 \mathrm{~nm}$ the upper energy level is partially drained by the pump itself. Therefore, not all of the achieved population inversion is used to amplify the signal [6], [12], [13]. In order to find the lowest power of the $980 \mathrm{~nm}$ co-propagating pump that could ensure the required quality of the signal, the system maximal BER values were observed at different pump powers of the pump at 37.5 , 50 and $100 \mathrm{GHz}$ channel spacing. The obtained results are shown in Fig. 3.

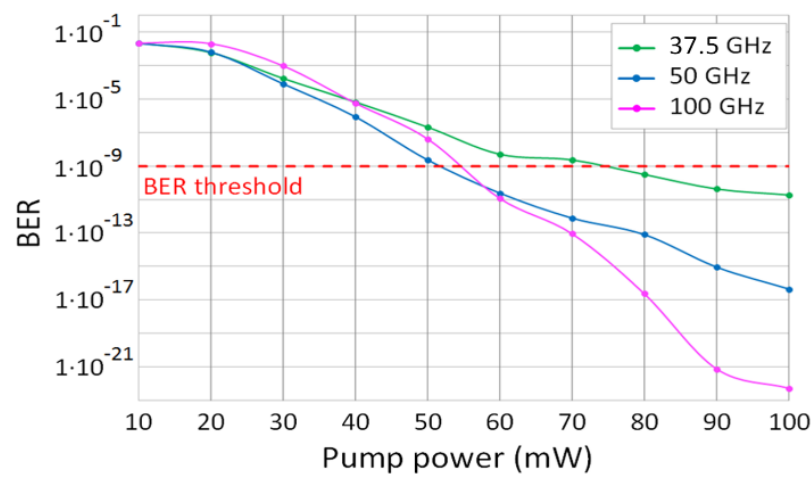

Fig. 3. Dependence of system maximal BER value on the power of the $980 \mathrm{~nm}$ co-propagating pump in the system with 37.5 (green), 50 (blue) and $100 \mathrm{GHz}$ (pink) channel spacing.

The results displayed in Fig. 3 show that for $37.5 \mathrm{GHz}$ channel spacing the minimal pump power that could ensure BER below the $1 \cdot 10^{-9}$ threshold was $80 \mathrm{~mW}$. This is by $20 \mathrm{~mW}$ more than in the case of $50 \mathrm{GHz}$ or $100 \mathrm{GHz}$ channel spacing - in both cases only $60 \mathrm{~mW}$ were enough to ensure the required signal quality. The fact that the minimal pump power that ensured the required signal quality was the same in systems with $50 \mathrm{GHz}$ and $100 \mathrm{GHz}$ channel spacing indicated that for channel spacing of $50 \mathrm{GHz}$ and higher the neighbouring channels caused inter-channel crosstalk that was too little to have a noticeable impact on the quality of the amplified signal.

It can also be seen that at lower pump powers in the system with $100 \mathrm{GHz}$ channel spacing higher BER values were observed than in the systems with lower 
channel spacing, but the situation changed with an increase in pump power. Such behaviour is caused by the EDFA gain spectrum slope - for $100 \mathrm{GHz}$ channel spacing the wavelength band used for transmission was two times broader than for $50 \mathrm{GHz}$ spacing. Due to the EDFA gain spectrum slope, in case of $100 \mathrm{GHz}$ channel spacing channels with higher wavelength would obtain less amplification than in case of $50 \mathrm{GHz}$ spacing; therefore, higher BER values were observed for these channels. At higher pump powers, the power of the channels becomes significant enough to induce arising of fibre non-linearity while being transmitted through the $2^{\text {nd }}$ SMF. The less the channel spacing, the more explicit the arising of four-wave mixing (FWM), which results in higher amount of inter-channel crosstalk produced by channel-channel FWM (CC-FWM) . Therefore, when increasing the pump power for higher values of channel spacing, BER values are decreasing more rapidly than in systems with lower channel spacing. The chosen amplifier configurations ensured the following gain and noise figure (NF) values:

- System with $37.5 \mathrm{GHz}$ channel spacing: the $80 \mathrm{~mW} 980 \mathrm{~nm}$ co-propagating pump ensured gain from $23.98 \mathrm{~dB}$ to $24.53 \mathrm{~dB}$ and NF from 4.47 to $4.5 \mathrm{~dB}$.

- System with $50 \mathrm{GHz}$ channel spacing: the $60 \mathrm{~mW} 980 \mathrm{~nm}$ co-propagating pump ensured gain from $22.38 \mathrm{~dB}$ to $23.33 \mathrm{~dB}$ and $\mathrm{NF}$ from 4.5 to $4.54 \mathrm{~dB}$.

- System with $100 \mathrm{GHz}$ channel spacing: the $60 \mathrm{~mW} 980 \mathrm{~nm}$ co-propagating pump ensured gain from $21.7 \mathrm{~dB}$ to $23.94 \mathrm{~dB}$ and $\mathrm{NF}$ from 4.48 to $4.56 \mathrm{~dB}$.

These results show that in the case of the WDM system with $37.5 \mathrm{GHz}$ spacing higher gain was required at approximately the same NF values to ensure BER below the $1 \cdot 10^{-9}$ threshold in comparison with systems with larger channel spacing. This can be explained by the fact that at $37.5 \mathrm{GHz}$ channel spacing, to avoid inter-channel crosstalk from the neighbouring channels, the bandwidth of the optical filters needs to be so small, that it filters out a part of energy of the corresponding channel signal. This is why higher gain should be obtained to ensure the required signal power at the input of the photodetector. Such additional amplification was not required in the case of $50 \mathrm{GHz}$ and $100 \mathrm{GHz}$ channel spacing, as such spacing is high enough to avoid the previously described inter-channel crosstalk. Furthermore, as mentioned previously, inter-channel crosstalk produced by CC-FWM is more explicit in systems with lower channel spacing. Therefore, additional amplification was required in the system with $37.5 \mathrm{GHz}$ channel spacing in order to compensate the signal impairments produced by CC-FWM.

To assess the EDFA performance, the dependences of BER values in the channels with the worst signal quality (in which BER values above the $10^{-9}$ threshold were detected first) on the power of the detected signal were obtained for all observed channel spacing values, and the results were compared with the same results obtained in WDM systems with the corresponding channel spacing but without amplification. The obtained results are shown in Fig. 4. 


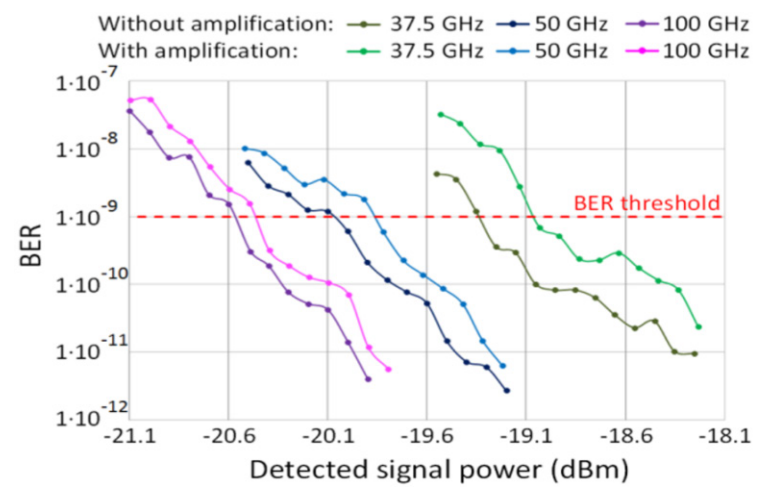

Fig. 4. Dependence of BER values in the channels with the worst signal quality on the power of the detected signal for three values of channel spacing in the WDM system with inline EDFA (37.5 GHz - green, $50 \mathrm{GHz}$ - blue, $100 \mathrm{GHz}$ - pink) and without amplification

(37.5 GHz - olive, $50 \mathrm{GHz}$ - dark blue, $100 \mathrm{GHz}$ - violet).

Figure 4 shows that in the system with $100 \mathrm{GHz}$ channel spacing implementation of the EDFA resulted in $0.1 \mathrm{~dB}$ power penalty in respect to the system without amplification, in the case of $50 \mathrm{GHz}$ channel spacing $-0.18 \mathrm{~dB}$, and in the case of $37.5 \mathrm{GHz}$ channel spacing $-0.22 \mathrm{~dB}$. It can be concluded that the smaller the channel spacing, the higher the power penalty. In all three cases, major part of power penalty is related to ASE noise produced by the EDFA. The NF values were approximately the same in all three cases; therefore, ASE produced by the EDFA was not the factor that caused the difference in power penalty. The cause of this difference was interchannel crosstalk produced by fibre non-linearity. When the power of the signal is high enough, fibre nonlinearity arises during transmission, including CC-FWM and self-phase modulation (SPM) nonlinear effects. The efficiency of FWM increases with a decrease in the wavelength difference between the interacting spectral components. Therefore, the smaller the channel spacing, the higher the observed efficiency of FWM that occurs between the channels, and the higher amount of interchannel crosstalk is produced. The presence of SPM also results in inter-channel crosstalk at relatively small values of channel spacing, as it causes broadening of the spectrum of the channels and results in overlapping of neighbouring channel spectra.

\section{INVESTIGATION OF EDFA POSITIONING IMPACT ON THE QUALITY OF THE AMPLIFIED SIGNAL}

From the perspective of amplifier positioning, amplifiers can be used in three different ways:

- As power boosters - the amplifier is placed at the output of the receiver block and is used to boost signal power right before sending it through the transmission fibre.

- As in-line amplifiers - the amplifier is placed in between two spans of transmission fibre and is used to compensate accumulated signal attenuation while the power of the signal is not too low for amplification or detection. 
- As preamplifiers - the amplifier is placed at the input of the receiver block and is used to amplify the signal right before detection [6].

In this section, the authors investigate and compare the performance of the EDFA when it is used as a power booster, as an in-line amplifier or as a preamplifier. To reach this goal, a simulation model of a 9.953 Gbps WDM transmission system with NRZ-OOK modulation and total transmission distance of $100 \mathrm{~km}$ was introduced. Three different EDFA positioning scenarios were implemented - when the EDFA was used as a preamplifier (Fig. 5.A), as an in-line amplifier (Fig. 5.B) and as a preamplifier (Fig. 5.C).

The frequency region used for transmission in the simulation model shown in Fig. 5 was from $193 \mathrm{THz}$ to $193.75 \mathrm{THz}$ with $50 \mathrm{GHz}$ channel spacing between the neighbouring channels - such setup was selected as per ITU-T G.694 grid for DWDM applications. The output radiation of all transmitters was combined and sent through a $100 \mathrm{~km}$ long transmission line that consisted of two $50 \mathrm{~km}$ long spans of standard SMF. When the EDFA was used as a power booster it was placed at the input of SMF1, when it was used as an in-line amplifier it was placed in between SMF1 and SMF2, and when it was used as a preamplifier - at the very input of the receiver block, after the FBG. EDF length and the parameters of the pumping radiation were selected in a way to obtain the minimal pump power that could ensure BER values below the $10^{-9}$ in all channels. Therefore, it was decided that the singlepump solution should be used in all three EDFA positioning scenarios. Same as in the previous section, it was decided to use the $980 \mathrm{~nm}$ co-propagating pump for obtaining population inversion in the EDF. Since in all three scenarios the power of the signal at the input of the EDFA was different, the length of the EDF was selected specifically for each EDFA positioning scenario.

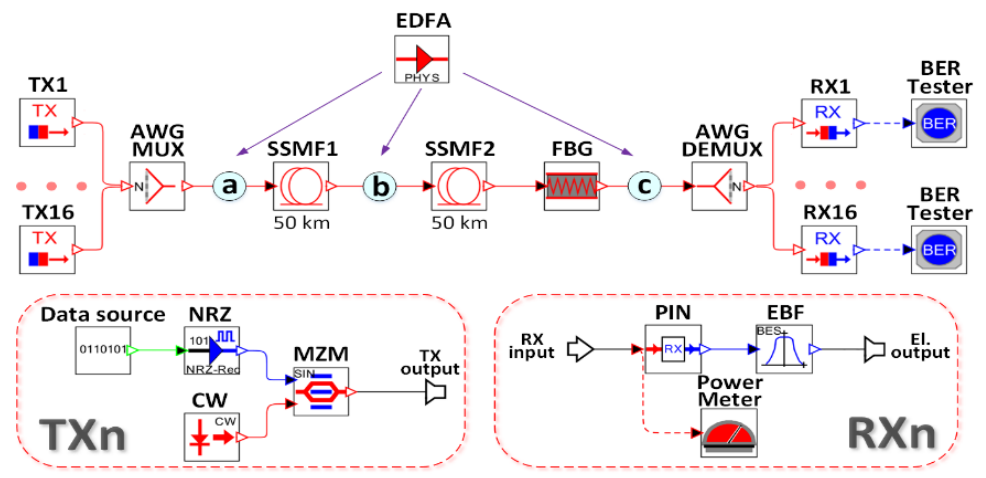

Fig. 5. Simulation model of the 16 channel $9.953 \mathrm{Gbit} / \mathrm{s}$ WDM transmission system with NRZ-OOK modulation and different EDFA positioning scenarios: (a) - as a power booster, (b) - as an in-line amplifier, (c) - as a preamplifier.

When choosing the configuration of the booster EDFA different combinations of EDF length and pump power were considered - the length of the EDF was changed from 5 metres to 15 metres and the dependence of systems maximal BER value on the power of the $980 \mathrm{~nm}$ co-propagating pump was obtained for each specific length of the EDF. Part of these results is shown in Fig. 6.A. 

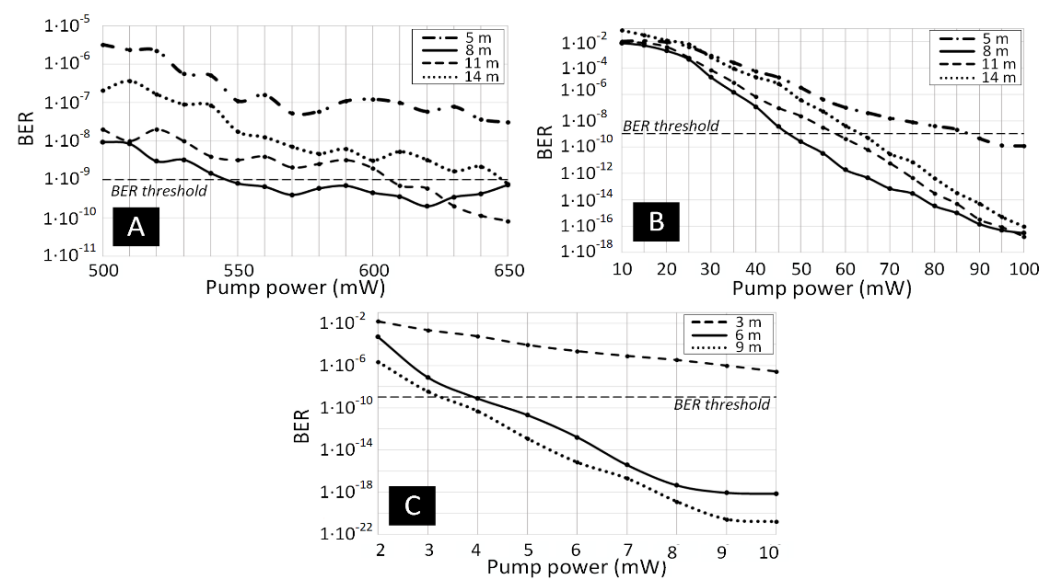

Fig. 6. Dependence of systems maximal BER value on the pump power of the booster (A) and the in-line (B) EDFA at EDF length of 5, 8, 11 and 14 metres, and of the preamplifier EDFA (C) at EDF length pf $3,6,9$ metres.

Figure 6.A shows that the lowest pump power that ensured BER values below the $1 \cdot 10^{-9}$ threshold was $550 \mathrm{~mW}$ at EDF length of 8 metres $\left(7.92 \cdot 10^{-10}\right.$ observed in the $15^{\text {th }}$ channel). Based on these results, $550 \mathrm{~mW} 980 \mathrm{~nm}$ co-propagating pump and 8-metre long EDF was chosen for the system with the booster EDFA. The power of the signal at the input of the booster EDFA was $9.06 \mathrm{dBm}$. The on-off gain and NF of the EDFA with the above configuration varied from $12.74 \mathrm{~dB}$ to $12.94 \mathrm{~dB}$ and from $5.03 \mathrm{~dB}$ to $5.19 \mathrm{~dB}$ respectively among all 16 channels.

For EDF length below 8 metres the maximal achievable population inversion was not enough to ensure such level of amplification that could compensate the total optical loss in the system, because at such high input signal power the amplifier was operating in the saturation mode. The following tendency was observed - the longer the EDF, the higher the slope of the gain spectrum. Due to this slope of the provided on-off gain, some channels obtained less gain at a certain pump power than at a shorter EDF length; therefore, higher pump power was required to ensure a certain level of amplification for these channels. As a result, for EDF length greater than 8 metres a higher level of amplification could be achieved, but due to the slope of the gain spectrum higher pump power was required for the gain to be sufficient for all channels.

While configuring the in-line EDFA, the length of the EDF was changed from 5 to 15 metres and the power of the pump - from 10 to $100 \mathrm{~mW}$ for each specific length of the EDF. The obtained systems maximal BER value - pump power dependencies for EDF length of 5, 8, 11 and 14 metres are displayed in Fig. 6.B. As it is shown in Fig. 6.B, like in the case of the booster EDFA, the minimal pump power that could ensure the required quality of the signal was observed when an 8 metre-long EDF was used, but this pump power was 11 times lower than in case of the booster EDFA (BER 2.7 $10^{-10}$ observed in the $13^{\text {th }}$ channel). Such EDFA configuration ensured from $12 \mathrm{~dB}$ to $12.88 \mathrm{~dB}$ on-off gain and from $5.12 \mathrm{~dB}$ to $5.3 \mathrm{~dB}$ NF values in the frequency region used for transmission.

Such significant difference between the system with the booster and the in-line EDFA in pump power required to ensure approximately the same level of 
amplification could be explained by the difference of signal power at the input of these two amplifiers: input signal with higher power needed more population inversion to get the same gain in $\mathrm{dB}$ than an input signal with lower power, and to achieve such high population inversion higher pump power was required. In case of the in-line EDFA the power of the input signal was by $10.02 \mathrm{~dB}$ lower than in the booster EDFA (just $-0.96 \mathrm{dBm}$ ). In case of the booster EDFA after amplification the power of the signal increased by $148.95 \mathrm{~mW}$ (from $8.05 \mathrm{~mW}$ to $156.5 \mathrm{~mW}$ ), but in case of the in-line EDFA - by $12.83 \mathrm{~mW}$ (from $1.24 \mathrm{~mW}$ to $14.07 \mathrm{~mW}$ ).

While configuring the preamplifier EDFA, the length of the EDF was increased from 3 to 9 metres and the power of the pump - from 2 to $10 \mathrm{~mW}$ for each specific length of the EDF. The obtained systems maximal BER value - pump power dependencies for EDF length of 3, 6 and 9 metres are displayed in Fig. 6.C. Figure 6.C shows that for the preamplifier EDFA just $4 \mathrm{~mW}$ of pump power at EDF length of 6 metres is enough to compensate the accumulated optical loss and to ensure BER values below $1 \cdot 10^{-9}\left(7.59 \cdot 10^{-10}\right.$ was observed in the $4^{\text {th }}$ channel). Such amplifier configuration amplified the signal by $12.43-12.66 \mathrm{~dB}$ and ensured NF values from 5.26 to $5.48 \mathrm{~dB}$ in the frequency region used for transmission. The obtained results showed that for EDF length from 7 metres to 9 metres $4 \mathrm{~mW}$ was also enough to ensure the required quality of the signal, but at this point it was decided to use the shortest EDF. The total signal power at the input of the EDFA was just $-13.94 \mathrm{~mW}$, and after amplifying the signal by $12.43-12.66 \mathrm{~dB}$ its power increased just by $0.7152 \mathrm{~mW}$ (from $0.0404 \mathrm{~mW}$ to $0.7556 \mathrm{~mW}$ ).

In order to determine the impact of EDFA positioning on the quality of the amplified signal, dependences of BER values on the power of the detected signal were observed in the channel with the worst signal quality (with the highest BER) in case of all three EDFA positioning scenarios, and these results were compared with the same results obtained in the corresponding channels of the same system without amplification. The obtained results in case of the booster EDFA are shown in Fig. 7(A), in case of the in-line EDFA - in Fig. 7(B) and in case of the preamplifier EDFA - in Fig. 7(C).

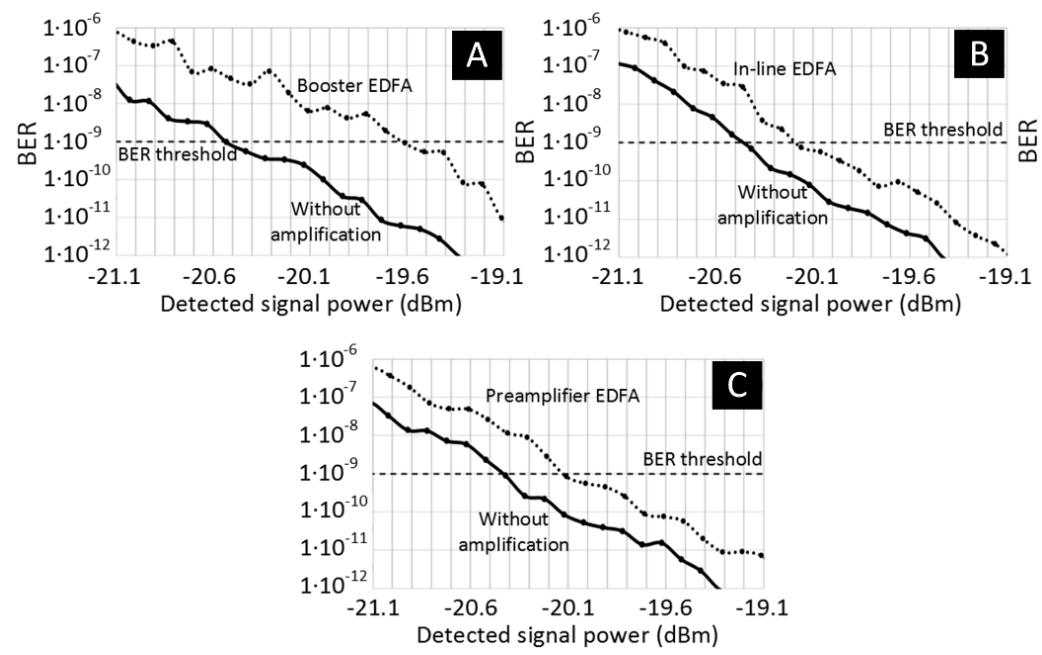

Fig. 7. Dependence of BER values on the power of the detected signal in the channels with the worst signal quality in the system without amplification (solid line) and with amplification (dotted line): (a) - power booster, (b) - in-line EDFA and (c) - preamplifier. 
As can be seen from Fig. 7, when the EDFA was used as a power booster 0.92 $\mathrm{dB}$ of power penalty was observed in respect to the system without amplification, when it was used as an in-line amplifier - just $0.26 \mathrm{~dB}$, and when it was used as a preamplifier $-0.31 \mathrm{~dB}$. Part of this power penalty is caused by ASE noise. The remaining part of the power penalty in case of the power booster EDFA is related to inter-channel crosstalk produced by CC-FWM and SPM fibre non-linearity, which has arisen during transmission due to high power of the signal after amplification.

In cases when the EDFA was used as an in-line amplifier and a preamplifier, signal impairments produced by fibre non-linearity were not observed as the power of the signal at EDFA output was insufficient to cause any non-linear behaviour. The power penalty in respect to the system without amplification in case when the EDFA was used as a preamplifier was by $0.05 \mathrm{~dB}$ higher than in the case when the amplifier was placed in between the two spans of SMF. In the preamplifier scenario, the power of the signal at EDFA input was by $13 \mathrm{~dB}$ lower than in the in-line amplifier scenario and, therefore, could not use the obtained population inversion as efficiently as in the case of the in-line amplifier. As a result, the unused part of the achieved population inversion eventually resulted in producing additional ASE noise that caused the afore-mentioned additional $0.05 \mathrm{~dB}$ of power penalty.

\section{CONCLUSIONS}

While investigating the impact of changes in channel spacing on the desired EDFA configuration and its performance, the following conclusions have been made:

- Additional pumping may be required to ensure certain quality of the signal for channel spacing as low as $37.5 \mathrm{GHz}$ to compensate the filtering out of part of the corresponding channel signal energy due to the presence of inter-channel crosstalk from the neighbouring channels.

- The dependence of the EDFA gain spectrum slope on the achieved level of population inversion and the impact of fibre non-linearity on the quality of the signal need to be considered while selecting the channel spacing in transmission systems with EDFAs. Due to the slope of the gain spectrum at lower pump powers in the system with $100 \mathrm{GHz}$ channel spacing higher BER values have been observed than in systems with lower channel spacing. However, with an increase in pump power the situation becomes completely opposite as the gain spectrum becomes more even and as arising of fibre non-linearity becomes more explicit at lower values of channel spacing.

- If the power of the signal after amplification is significant enough to cause arising of fibre non-linearity then the smaller channel spacing is used, the higher the amount of inter-channel crosstalk produced by channelchannel FWM and the higher power penalty is observed in respect to a system without amplification. For $100 \mathrm{GHz}$ channel spacing, this power penalty was equal to $0.1 \mathrm{~dB}$, for $50 \mathrm{GHz}$ channel spacing $-0.18 \mathrm{~dB}$, and for $37.5 \mathrm{GHz}$ channel spacing $-0.22 \mathrm{~dB}$. 
The following conclusions have been made while investigating the impact of EDFA positioning on the desired EDFA configuration and its performance:

- The higher the power of the signal at the input of the EDFA, the higher population inversion is required to ensure approximately the same level of amplification. To achieve a higher level of population inversion, higher pump power (and in some cases longer EDF) is required.

- At a certain point, decreasing signal power at amplifier input causes degradation of the quality of the amplified signal, as its power becomes insufficient to effectively consume the obtained population inversion. As a result, the unused population inversion causes an additional ASE noise that has negative impact on the amplified signal quality.

After summarising all of the previously mentioned results, it is evident that any change in the EDFA operating conditions (such as channel spacing or EDFA positioning) will impact the performance of the amplifier, and, therefore, after such changes the EDFA needs to be re-configured in order to use the amplifier as effectively as possible.

\section{REFERENCES}

1. Cisco Inc. (2018). Cisco visual networking index: Forecast and trends, 2017-2022. White paper.

2. Hamaide, J.P. (2015). Optical networks: recent breakthroughs and future challenges. France: Alcatel-Lucent Bell Labs CominLabs Days.

3. Morita, I., \& Peng, W.R. (2012). High capacity WDM transmission using terabit superchannels. In 38th European Conference and Exhibition on Optical Communications, 16-20 September 2012, Amsterdam, Netherlands, DOI:10.1364/ECEOC.2012.Th.2.C.3.

4. Digonnet, M. J. F. (2001). Rare-earth-doped fiber lasers and amplifiers (2nd ed.). USA: CRC Press.

5. Putrina, J., Olonkins, S., \& Bobrovs, V. (2017). Investigation of amplification span length impact on the quality of the signal in WDM transmission systems with erbium-doped fiber amplifiers. In 2017 Progress in Electromagnetics Research Symposium (PIERS 2017), 22-25 May 2017, St. Petersburg, Russia. DOI:10.1109/PIERS.2017.8262033

6. Becker, P.C., Olsson, N.A., \& Simpson, J.R. (1999). Erbium-doped fiber amplifiers: Fundamentals and technology. USA: Academic Press.

7. Putrina, J., \& Bobrovs, V. (2016). Evaluation of erbium doped fiber amplifier application in fiber optics transmission systems. In 2016 Progress in Electromagnetics Research Symposium (PIERS 2016), 8-11 August 2016, Shanghai, China. DOI:10.1109/ PIERS.2016.7735428

8. Sun, Y., Srivastava, A. K., Zhou, J., \& Sulhoff, J.W. (1999). Optical fiber amplifiers for WDM optical networks. Bell Labs Technical Journal, 4(1), 187-206.

9. Trifonovs, I., Bobrovs, V., \& Ivanovs, G. (2011). Optimization of a standard bidirectional DWDM solution. Electronics and Electrical Engineering, 115(9), 37-40.

10. Synopsys Inc. (2014). Synopsys RSoft solutions. Product Catalogue.

11. Ivanovs, G., Bobrovs, V., Olonkins, S., Alsevska, A., Gegere, L., \& Parts, R. (2014). Application of the erbium-doped fiber amplifier in wavelength division multiplexing 
(WDM) transmission systems. International Journal of Physical Sciences, 9(5), 91-101.

12. Putrina, J. (2016). EDFA characteristics and working principle evaluation in FOTS. M.S. thesis. Riga: Riga Technical University.

13. Berezins, S., \& Bobrovs, V. (2013). EDFA application research in WDM communication systems. Electronics and Electrical Engineering, 19(2), 92-96.

\section{EDFA PASTIPRINĀTĀJU DARBĪBAS IZPĒTE DAŽĀDOS EKSLPLUATĀCIJAS APSTĀKL,OS DWDM SAKARU SISTĒMĀS}

J. Putrina, S. Olonkins, V. Bobrovs, J. Poriņš

Kopsavilkums

Šajā darbā ir izpētīta EDFA pastiprinātāju darbība atkarībā no tā ekspluatācijas apstākḷiem. Pirmkārt, ir apskatīta starpkanālu intervāla izmaiņas ietekme uz pastiprināma signāla kvalitāti un uz optimālo EDFA konfigurāciju. Rezultāti tika iegūti pie trīs dažādiem starpkanālu intervāliem - $37.5 \mathrm{GHz}, 50 \mathrm{GHz}$ un $100 \mathrm{GHz}$. Otrkārt, tika novērtētā EDFA izvietojuma ietekme uz pastiprināmā signāla kvalitāti un uz optimālo EDFA konfigurāciju. Tika izskatīti trīs EDFA izvietojuma scenāriji kad EDFA tika izmantots kā jaudas pastiprinātājs, kā līnijas pastiprinātājs un kā priekšpastiprinātājs. Visās apskatītās pārraides sistēmu konfigurācijās tika atrasta tāda EDFA pastiprinātāja konfigurācija kas spēja nodrošināt bitu-kḷūdu attiecību zem $1 \cdot 10^{-9}$ vērtības visos pārraides sistēmas kanālos, izmantojot pēc iespējas zemāku pumpējošā starojuma jaudu. Pastiprinātāju darbības novērtēšanai pie katras izvēlētas EDFA konfigurācijas tika iegūtas nepieciešamās jaudas pieauguma vērtības attiecībā pret identisku pārraides sistēmu bez optiskā signāla pastiprināšanas.

18.02.2019. 